\title{
Compressive Strength of Fly ash-based Geopolymer Concrete with a Variable of Sodium Hydroxide $(\mathrm{NaOH})$ Solution Molarity
}

\author{
Herwani $^{1,}{ }^{*}$, Ivindra Pane $^{2}$, Iswandi Imran $^{2}$, and Bambang Budiono ${ }^{2}$ \\ ${ }^{1}$ Doctoral Program Student, Faculty of Civil and Environmental Engineering, ITB Bandung 40132, Indonesia \\ ${ }^{2}$ Professor at Faculty of Civil and Environmental Engineering, ITB Bandung 40132, Indonesia
}

\begin{abstract}
Geopolymer concrete is a new material made by activating the raw materials which contain many elements of silica and alumina. Compressive strength of geopolymer concrete produced was influenced by the concentration of the activator solution. This paper presents an experimental investigation into fly ash-based geopolymer concrete. Research objective was to investigate the effects of alkaline activator solution (AAS) molarity on compressive strength of geopolymer concrete. Variable of the test were a solution to sodium hydroxide was chosen as the activator solution. Concentration of sodium hydroxide solution used was $10 \mathrm{M}, 12 \mathrm{M}$ and $14 \mathrm{M}$ with ambient curing. The specimen is made of concrete cylinder with diameter $10 \mathrm{~cm}$ and height $20 \mathrm{~cm}$ as many as 9 pieces each variable. Compressive strength tests is performed when the concrete is 7,14 , and 28 days old. Results of the test are indicated that the increasing of sodium hydroxide $(\mathrm{NaOH})$ solution concentration leads to improve the compressive strength of geopolymer concrete. The optimal compressive strength of geopolymer concrete was achieved at a concentration of sodium hydroxide solution $(\mathrm{NaOH})$ of $12 \mathrm{M}$. Geopolymer concretes compressive strength only achieves around $50-60 \%$ of the planned.
\end{abstract}

\section{Introduction}

Geopolymer concrete is a kind of concrete that not uses Portland cement (PC) $[1,2]$. Fly ash is one of the materials that can be used as a binder in its mixture [2, $3]$. The geopolymer concrete is formed from a chemical reaction and not from hydration reaction [4]. The most impressive characteristic is that geopolymer concrete has high compressive strength and durability $[5,6,7,8]$. One of the conclusions of the research result was that constrained geopolymer concrete material is one of the materials suitable to develop for earthquake-disposed to areas [9]. To obtain a good geopolymer concrete, the type of activator ought to be adjusted to the compound contained in fly ash. A proper composition is highly expected for a chemical reaction to take place perfectly. The activator usually used is Sodium Hydroxide $8 \mathrm{M}$ $14 \mathrm{M}$ and Sodium Silicate $\left(\mathrm{N}_{2} \mathrm{SiO}_{3}\right)$ at a ratio between 0.4 and 2.5 [5].

Different areas have coals with different mineral contents, so that the characteristics of fly ash produced greatly vary [8]. The composition of fly ash mineral content affects the characteristics of the mechanic properties of geopolymer concrete. Compressive strength is one of the main characteristics of concrete.

Some researchers have developed mixed designs with diverse curing methods and variables to make good quality geopolymer concrete. Palomo et al. [10] researched geopolymer concrete by using class-F fly ash material. They used four different solutions at a ratio of mass between alkaline activator and fly ash from approximately 0.25 to 0.30 . The ratio of the molars of $\mathrm{SiO}_{2} / \mathrm{K}_{2} \mathrm{O}$ or $\mathrm{SiO}_{2} / \mathrm{Na}_{2} \mathrm{O}$ solution was around $0.63-1.23$. Compressive strength was found after carrying out a curing for 24 hours at $65^{\circ} \mathrm{C}$, i.e., achieved more than 60 $\mathrm{MPa}$ for the mixture that used a combination of sodium hydroxide and sodium silicate activators. $\mathrm{Xu}, \mathrm{H}$ and van Deventer [11] conducted a research and reported that the ratio of alkali solution mass and alumina-silicate was approximately 0.33 for geopolymer reaction to take place. The maximum compressive strength obtained achieved $19 \mathrm{MPa}$ after curing for 72 hours at $35 \mathrm{oC}$. Van Jaarsveld et al. [12] conducted a research by using a ratio of alkali mass of 0.39 . The material used was $57 \%$ fly ash mixed with $15 \%$ kaolin. The alkaline solution was composed of $3.5 \%$ sodium silicate, $20 \%$ water, and $4 \%$ sodium or potassium hydroxide. The compressive strength obtained achieved $75 \mathrm{MPa}$. Hardjito and Rangan [5] conducted a research on a mixture of geopolymer concrete. The concentration of sodium hydroxide $(\mathrm{NaOH})$ used was around $8 \mathrm{M}-16 \mathrm{M}$. The ratio of mass between sodium silicate and sodium hydroxide was around 0.4-2.5. For the moment, the ratio of mass between alkaline activator and fly ash was around 35\%. In conclusion that the higher molarity of sodium hydroxide causes the higher compressive strength of geopolymer concrete. The mass ratio between sodium silicate and sodium hydroxide is high then the compressive strength produced by the geopolymer concrete will increase. Compressive strength of

\footnotetext{
* Corresponding author: herwaniuntan@yahoo.co.id
} 
geopolymer concrete by 7 days old achieved $67 \mathrm{MPa}$ after curing for 24 hours at $600 \mathrm{C}$. Januarti Jaya Ekaputri et al [13] conducted a research of the mechanical property of fly ash-based geopolymer concrete derived from Jawa Power Paiton. The variables used were activator solution molarity and ratio of sodium silicate (Na2SiO3) and sodium hydroxide (NOH). The optimum compressive strength was obtained at $10 \mathrm{M}$ molarity with a ratio of sodium silicate to sodium hydroxide 1.5. The compressive strength produced achieved 48.59 Mpa. Tabassum R.K [14] conducted a research on the effect of the concentration of sodium hydroxide solution on geopolymer concrete mixture. A maximum compressive strength by 28 days old was $40.21 \mathrm{MPa}$. Sodium Hydroxide $(\mathrm{NaOH})$ concentration gave a significant impact in enhancing the properties where the optimum concentration of $\mathrm{NaOH}$ of $12 \mathrm{M}$ gave better strength properties of geopolymer Concrete [15].

\section{Experimental Method}

\subsection{Materials}

Geopolymer concrete material used is taken from local query. Fine aggregate used Cimalaka sands, and coarse aggregate used stones derived from Cimahi. Classification of coarse aggregate is passes through 20$\mathrm{mm}$ and $10-\mathrm{mm}$ sieve. Classification of sand is passes through a $4.75-\mathrm{mm}$ sieve. The raw material fly ash from PLTU Suralaya waste was used. To activate silica and alumina elements and other contain in fly ash, alkaline solution was used. Sodium hydroxide and sodium sulphate were alkalis chosen activator in geopolymer concrete mixture. Sodium hydroxide was derived from a chemical store in form of flake. Sodium sulphate could be derived from chemical stores in bottle or drum container. Before being mixed in concrete, sodium hydroxide should be firstly solved according to the several of concentration. A XRF (X-ray fluorescence spectroscopy) test was done to determine the content of fly ash mineral. The content of elements in fly ash was as follows:

Table 1. The composition of chemical contents of Suralaya fly ash (in \% of weight)

\begin{tabular}{cccccccc}
\hline Fly Ash & $\mathrm{SiO}_{2}$ & $\mathrm{Al}_{2} \mathrm{O}_{3}$ & $\mathrm{Fe}_{2} \mathbf{O}_{3}$ & $\mathbf{C a O}$ & $\mathbf{M g O}$ & $\mathbf{N a}_{2} \mathbf{O}$ & $\mathbf{L o I}$ \\
\hline $\begin{array}{c}\text { Specimen } \\
\text { A }\end{array}$ & 42.29 & 17.41 & 12.10 & 10.47 & 7.39 & 1.38 & 6.15 \\
$\begin{array}{c}\text { Specimen } \\
\text { B }\end{array}$ & 41.91 & 17.21 & 12.01 & 10.39 & 7.31 & 1.48 & 5.86 \\
$\begin{array}{c}\text { Specimen } \\
\text { C }\end{array}$ & 42.25 & 17.48 & 11.88 & 10.34 & 6.91 & 1.43 & 6.26 \\
\hline
\end{tabular}

Super plasticizer was added on geopolymer concrete mixture to obtain good quality and workability. The quantity and kind of super plasticizer used as needed and recommended doses in Indonesian concrete standard (SNI).

\subsection{Mixed Design and Manufacture of Specimens}

The investigation of fine aggregate and coarse aggregate characteristics were done before making a mixed design. Sieve analysis is done on the coarse aggregate and fine aggregate. In addition to sieve analysis, there are also tests on specific gravity, water absorption, mud content, organic content and weight of volume. The results of the mud content on fine aggregate is $19.2 \%$, it is necessary to wash before use on concrete. After washing, the fine aggregate was again tested for mud content. The magnitude only reaches $2 \%$. The specific gravity of fine aggregate on SSD condition is 2,531 and water absorption is $2,147 \%$. Whereas density of coarse aggregate diameter $9.5-19.5 \mathrm{~mm}$ is 2,618 and water absorption 3,609\%.

The mixed design was created by using a nomogram proposed by Partogi. The nomogram is actually for paste phase geopolymer, but by a modification it can be used for geopolymer concrete mixed design. The nomogram shows the relation between the reactant molar ratio and weight of the aggregate to the paste ratio. The ratio of reactant molar was found from the comparison of water molarity and solid material molarity $(\mathrm{H} 2 \mathrm{O} / \mathrm{Na} 2 \mathrm{O}+\mathrm{SiO} 2+\mathrm{Al} 203)$. The composition of mixed design used can be seen on table 2 below.

Table 2. The composition of geopolymer concrete mixed design (in $\mathrm{Kg} / \mathrm{m} 3$ )

\begin{tabular}{ccc}
\hline Materials & Mix 1 & Mix 2 \\
\hline Coarse Aggregate (SSD) & 1200 & 1142.7 \\
Dia. $4.5-9.5 \mathrm{~mm}$ & 540 & 457.1 \\
Dia. $9.5-19.5 \mathrm{~mm}$ & 660 & 685.6 \\
Fine Aggregate (SSD) & 600 & 521.8 \\
Fly Ash & 450 & 410 \\
$\mathrm{NaOH}_{\text {Solutions }}$ & 80 & 110 \\
$\mathrm{Na}_{2} \mathrm{SiO}$ 3 Solutions & 120 & 120 \\
$\mathrm{Superplasticizer}_{\text {Added water }}$ & 9 & 8.2 \\
\end{tabular}

The mixing of concrete using a pan mixer. Each mixture was prepared with the concentration of $\mathrm{NaOH}$ solution being 10,12 , and $14 \mathrm{M}$. The specimens were cylindrical diameter $10 \mathrm{~cm}$ and height $20 \mathrm{~cm}$. Ambien curing performed on the specimens. The number of sample of 3 pieces for each variable. The tests were performed when geopolymer concrete was 7,14 , and 28 days old. Total sample is 27 pieces.

\section{Results and discussion}

\subsection{Fresh Geopolymer Concrete}

Characteristics of fresh geopolymer concrete is different from Portland cement-based normal concrete. The colour of geopolymer concrete is very dark (black), depending on the colour of the source of fly ash. The use of extra 
water in a very small amount of mixed design will have an effect on the characteristics of the geopolymer concrete. Fresh geopolymer concrete mixture behaves like a gel with a very thick consistency. In the first mixed design, there is no extra water. The mixture is rigid causing some porous specimens. Value of slump test was only $5 \mathrm{~cm}$. The second Mix design showed different behaviours than the first mix design. The mixture consistence was relatively liquid, so the mortar of fresh concrete was more elastic. The value of its slump test was around $12-16 \mathrm{~cm}$. Concrete casting into a mould was easier, and porous on the specimens became decreasing. Geopolymer concrete was more rapidly hardened as compared to Portland cement-based concrete. The result of observation during concrete casting in the mould, it needed around 150-250 minutes into hard. There was no bleeding on the surface during polymerization process. There were white stains on the surface of geopolymer concrete. The cause was sodium element existing in the concrete reacted with outside air to produce crystallization.

\subsection{Concrete compressive strength}

Fig. 1 and 2 showed the development of the compressive strength of geopolymer concrete at different concentration of $\mathrm{NaOH}$ solution. Maximum compressive strength of geopolymer concrete at 28 days was obtained on sodium hydroxide concentration of $14 \mathrm{M}$, i.e. 29.34 MPa. The biggest increase in compressive strength took place on a molarity of $12 \mathrm{M}$, i.e., $32.56 \%$, while on molarity of $14 \mathrm{M}$ it was only $8.51 \%$. Other behaviour shown by geopolymer concrete was that it has a high initial compressive strength. By 7 days old, geopolymer concrete with $\mathrm{NaOH}$ molarity of $14 \mathrm{M}$ has achieved 17.48 MPa. Then, the increase in concrete was not so large. The imperfect condition of sample, being porous, possibly caused less consistent behaviours. Fig. 3 showed the relation between the compressive strength of geopolymer concrete by 28 days old and the molarity of $\mathrm{NaOH}$. From the graphic it could be seen that the trend of increases in compressive strength on molarities of 12 $\mathrm{M}$ and $14 \mathrm{M}$ was not so significant. The indication that 12-M morality approached the optimal was not clearly seen yet. In the second mixture design, it could be seen that geopolymer concrete with the molarity of $\mathrm{NaOH}$ solution of $12 \mathrm{M}$ was the optimum mixture (Fig. 4).

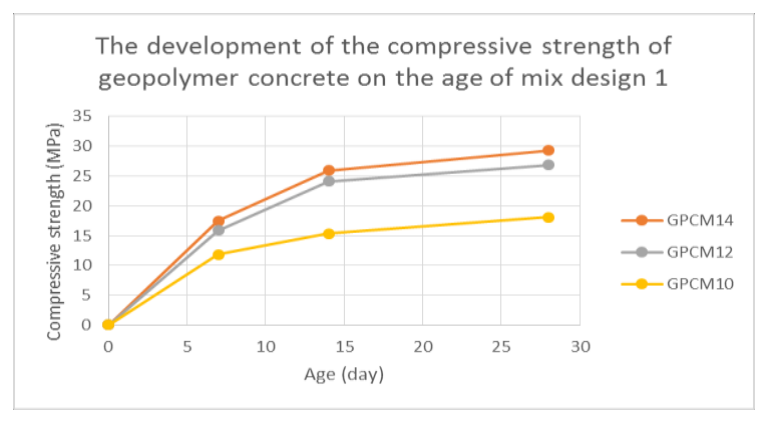

Fig. 1. The development of the compressive strength of geopolymer concrete on the age of the first mix design

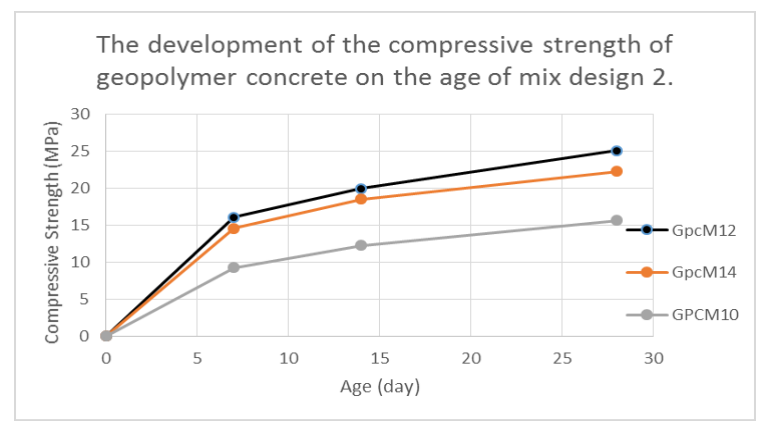

Fig. 2. The development of the compressive strength of geopolymer concrete on the age of the second mix design.

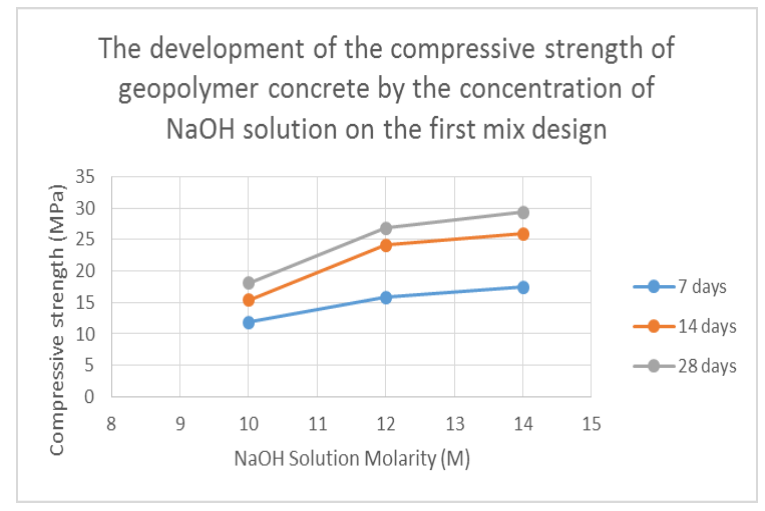

Fig. 3. The development of the compressive strength of geopolymer concrete by the concentration of $\mathrm{NaOH}$ solution on the first mix design.

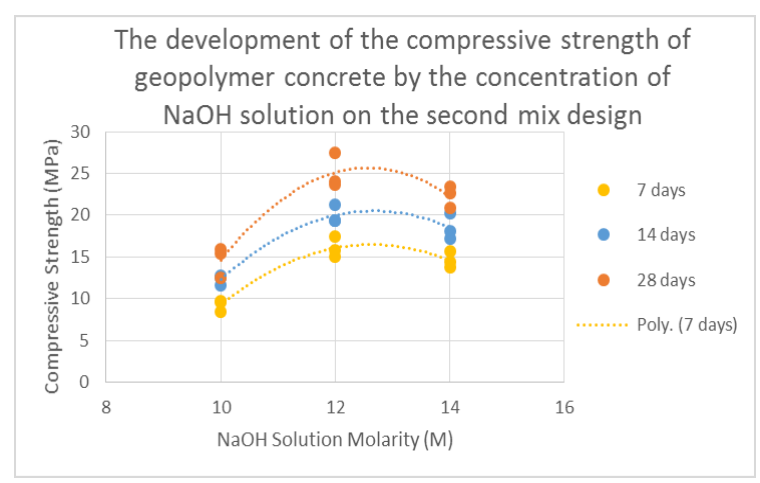

Fig. 4. The development of the compressive strength of geopolymer concrete by the concentration of $\mathrm{NaOH}$ solution on the second mix design

Compressive strength design of geopolymer concrete was $50 \mathrm{MPa}$ with a slump of $10-15 \mathrm{~cm}$. The compressive strength achieved was only $50-60 \%$ of the planned compressive strength. Hot curing on geopolymer concrete is strongly advised to get better concrete quality $[5,8]$. The compressive strength in the second mix design is decreased compared to the first mix design (Figure 5). This behaviour indicates that the quality of geopolymer concrete is very sensitive to the use of extra water. 


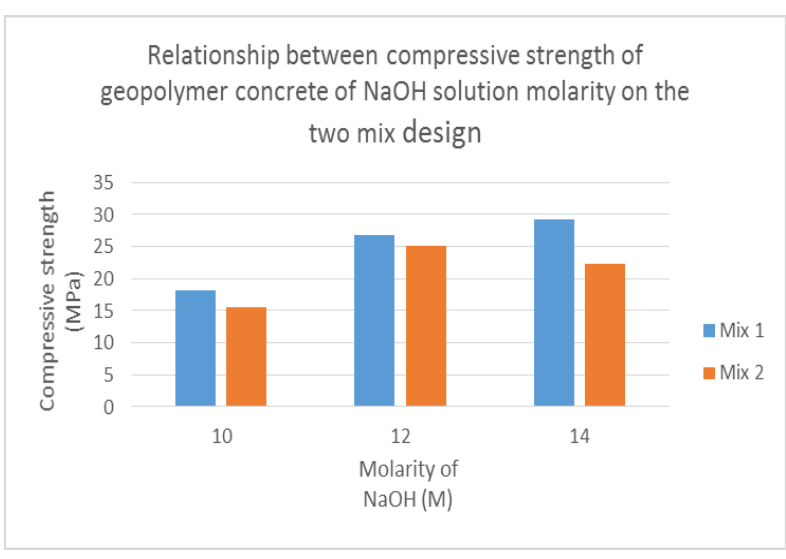

Fig. 5. The development of the compressive strength of geopolymer concrete by the concentration of $\mathrm{NaOH}$ solution on the two mix designs

\subsection{Shrinkage of Geopolymer Concrete}

Observation of shrinkage was conducted on the development of the weight of specimens. The observation was intended to see the effect of room temperature on the weight of geopolymer concrete. Figure 6 shows the development of the weight of specimen on various $\mathrm{NaOH}$ solution molarity. This indication was used to see the shrinkage on the weight of specimen.

The smallest shrinkage occurs in geopolymer concrete with the $\mathrm{NaOH}$ solution molarity of $14 \mathrm{M}$ (figure 6). Increasing the amount of water used in geopolymer concrete has resulted in shrinkage. The molarity of the $\mathrm{NaOH}$ solution decreases, the shrink percentage increases.

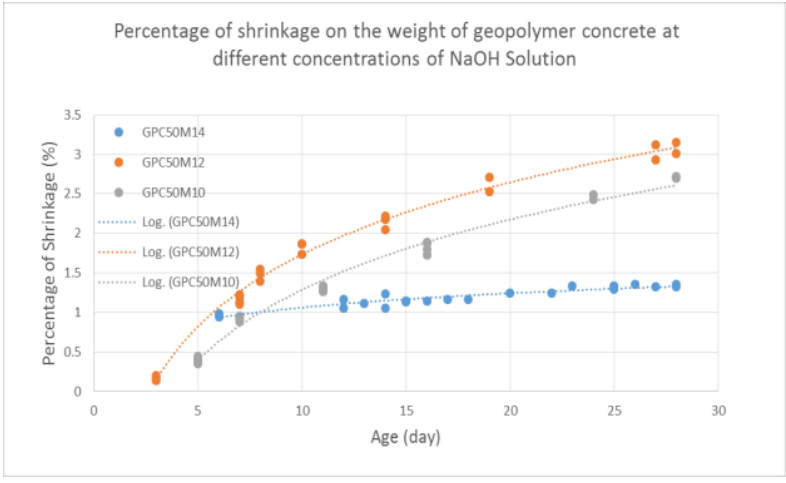

Fig. 6. Percentage of shrinkage on the weight of geopolymer concrete at different concentrations of $\mathrm{NaOH}$

\section{Conclusions}

Fresh geopolymer concrete has a high consistency so the behaviour of mixture is rigid. This characteristic could be improved by adding super plasticizer so that the mortar becomes more elastic and workable. The setting time was faster by 150-250 minutes, observed during producing concrete mixture. The higher concentration of $\mathrm{NaOH}$ solution then the required setting time becomes longer Geopolymer concrete achieved an optimum compressive strength on $\mathrm{NaOH}$ solution molarity of 12 M. The compressive strength achieved was only $50-60 \%$ of the planned one. The smallest shrinkage took place on geopolymer concrete with $\mathrm{NaOH}$ solution molarity of 14 M.

Acknowledgements: This research was funded by Directorate General of Higher Education Indonesia through Excellent Research for Higher School Grant. We also thank to PLTU Suralaya for providing fly ash.

\section{References}

1 Herwani, I. Imran, I. Pane, Studi Eksperimental Karakteristik Beton Geopolimer Berbahan Dasar Fly Ash, Prosiding (KNPTS), Goro, G.L. (eds), pp. 87 (2015)

2 P.H. Simatupang, I. Imran, I. Pane, \& B. Sunendar, On the Development of a Nomogram for Alkali Activated Fly Ash Material (AAFAM) Mixtures, Journal of Engineering Technology \& Science, Vol. 47, No. 3, 231-249 (2015)

3 Siyal, A.A., Azizli, K.,A., Man, Z., \& Ullah, H., Effects of Parameters on the Setting Time of Fly Ash Based Geopolymers Using Taguchi Method, in Proceedings 4th International Conference on Process Engineering and Advanced Materials, Procedia Engineering 148, pp. 302 - 307 (2016).

4 J. Davidovits, 'Chemistry of geopolymeric systems, terminology', in Proceedings of Second International Conference on Geopolymer, pp. 940 (1999)

5 D. Hardjito, \& B.V. Rangan, Development and properties of low-calcium fly ash-based geopolymer concrete, Research Report, Perth, Australia: Curtin University of Technology (2005)

6 P. Duxson, A. Fernandez-Jimenez, J.L. Provis, G.C. Lukey, A. Palomo, \& J.S.J. Van Deventer, Geopolymer Technology: The Current State of the Art, Material Science, 42, pp. 2917-2933 (2007)

7 F. Pacheco-Torgal, J. Castro-Gomes, \& S. Jalali, Alkali Activated Binders: A review, Part 1, Historical Background, Terminology, Reaction Mechanisms and Hydration Products, Construction and Building Materials, 22, pp. 1305-1314 (2008).

8 P.H. Simatupang, 'Development of Alkali Activated Material to Make Green Material of Infrastructures', $\mathrm{PhD}$ Dissertation, Civil and Environment engineering, ITB, Bandung (2013)

9 N. Ganesan, R. Abraham, S. Deepa Raj, \& D. Sasi, Stress-strain behaviour of confined Geopolymer concrete, Construction and Building Materials, Elsevier, pp.326-331 (2014)

10 A. Palomo, M.W. Grutzeck, \& M.T. Blanco, Alkali-Activated fly ash cement for future, Cement and Concrete Research, 29 (8); pp.1323-1329 (1999)

$11 \mathrm{H} . \mathrm{Xu}$, and J.S.J. Van Deventer, The Geopolymerisation of Alumino Silicate Minerals, International Journal of Mineral Processing 59 (3): 247-226 (2000) 
12 J.G.S. Van Jaarsveld, J.S.J. Van Deventer, \& G.C. Lukey, The effect of composition and temperature on the properties of fly ash and kaolinite-based geopolymers, Chemical Engineering Journal, 4001:1-11, (2002)

13 J.J. Ekaputri, Triwulan, dan O. Damayanti, Sifat Makanik Beton Geopolimer Berbahan Dasar Fly Ash Jawa Power Paiton Sebagai Material Alternatif Jurnal PONDASI, volume 13 no.2 (2007)

14 R.K. Tabassum, A. Khadwal, Effect of Sodium Hydroxide Concentration on Various Properties of Geopolymer Concrete, IJETR pp. 2454-4698, Vol.3, Issue-10, October (2015)

15 R. M. Hamidi, Z. Man, K.A. Azizli, Concentration of $\mathrm{NaOH}$ and the Effect on the Properties of Fly Ash Based Geopolymer, 4th International Conference on Process Engineering and Advanced Materials, Procedia Engineering 148, pp. 189 193, (2016) 